\title{
SOBRE COMO NÃO IR EMBORA: MEMÓRIA E METANARRATIVA EM AINDA ESTOU AQUI, DE MARCELO RUBENS PAIVA
}

\section{ABOUT NOT GOING THROUGH: MEMORY AND METANARRATIVE IN AINDA ESTOU AQUI, BY MARCELO RUBENS PAIVA}

Maricelma da Silva ${ }^{1}$

Luís Fernando Prado Telles ${ }^{2}$

\begin{abstract}
RESUMO: O presente artigo busca investigar o aspecto dual da narrativa de Ainda estou aqui, especificamente a oscilaçăo entre narrativa e comentário, processo metanarrativo este que funciona como estratégia de reconstrução da memória do autor e de sua família, vítimas do estado de exceçăo que se instaurou no país durante o período do regime militar. O estudo pretende investigar ainda em que medida o trabalho de construçăo narrativa funciona de modo a demarcar a resistência da memória e o restabelecimento de verdades históricas.
\end{abstract}

Palavras-chave: memória; metanarrativa; resistência; estado de exceçăo; regime militar.

\begin{abstract}
The present article seeks to investigate the dual aspect of the narrative of Ainda estou aqui, specifically the oscillation between narrative and commentary, a metanarrative process that functions as a strategy to reconstruct the memory of the author and his family, victims of the state of exception that was established the during the period of the military regime. The study intends to investigate to what extent the work of narrative construction works in order to demarcate the resistance of memory and the restoration of historical truths.
\end{abstract}

Keywords: memory; metanarrative; resistance; state of exception; military regime.

Marcelo Rubens Paiva afirma, em diferentes eventos e entrevistas, que Ainda estou aqui é um livro de memórias, além de conter evidentes traços de uma escrita autobiográfica. A despeito de uma classificaçăo genérica, se livro de memórias ou autobiografia, o fato é que a sua narrativa funciona de modo a construir o que poderíamos designar, num sentido lato, como sendo um tipo de escrita da verdade.

1 Mestre em Letras pela Universidade Federal de Săo Paulo (2018).E-mail: maricelmada.silva@gmail.com

2 Professor de Teoria Literária da Escola de Filosofia, Letras e Ciências Humanas da Universidade Federal de Sáo Paulo (UNIFESP). Doutor em Teoria e História Literária pela Universidade Estadual de Campinas (UNICAMP).E-mail: lf.telles@hotmail.com 
A escrita da verdade, nesse caso, apresenta uma particularidade, visto que se faz pela presença de um narrador que se alterna entre o narrar e o comentar para reconstituir a memória (sua e de seus pais). Para tanto, esse narrador se movimenta atentando para a produçáo de uma narrativa fluída, na qual o leitor năo tenha dúvidas da veracidade dos fatos contados, nem questione os impactos que essa leitura ocasiona. $\mathrm{O}$ narrador procura reconstruir a história e a memória através do discurso, sem, contudo, deixar de comentar esse processo: ele está tăo próximo da história que pode ousar e lançar máo de recursos da narrativa; pode se movimentar, se ausentar, lançar dúvidas.

Ao narrar a trajetória de seu pai, uma personagem histórica por seu envolvimento e atuaçáo na política em um momento de derrubada da democracia no Brasil, descreve a sobrevivência da máe e as diversas batalhas que ela travou para criar cinco crianças praticamente sozinha e descobrir o que de fato aconteceu ao seu marido. $O$ narrador de Marcelo Rubens Paiva realiza desabafos, em seus comentários é irônico, desconfiado e ao mesmo tempo reconstitui a história e a memória permeadas por uma alegria perturbadora - muito do que conseguiu rememorar estava passível de nunca ser contado - a homenagem sempre presente quando fala da măe (Eunice) é um sinal nâo só de reverência como também de satisfaçăo por poder, finalmente, celebrar a chegada de respostas, consideradas por essa família como vitórias comemoradas após décadas de procuras e espera.

De acordo com Lejeune (2014, p. 186), "essa memória tem forma, manias, estratégias, năo é inerte, mesmo se ainda năo se expressou ou é virtual" e, por isso, apenas contar parece pouco, é preciso comentar para equilibrar seus papéis. Um mesmo narrador se coloca objetivamente ao mostrar a história, ao passo que se alterna e também é subjetivo ao construir a memória intervindo, comentando, analisando implicitamente.

A chamada escrita da verdade se apresenta, nesse caso, na articulaçăo entre o discurso e a narrativa. A memória é (re)construída a partir desse processo em que acontecimentos considerados chaves se interpóem a rupturas, ou seja; "o discurso da memória é um labirinto" (LEJEUNE, 2014, p.187), cabendo ao narrador relacionar os fatos passados aos do presente, reconstituí-los, dar continuidade, ir pelo caminho metanarrativo:

Se tudo é recriaçâo de algo já inventado, nada é invençâo. Sei que repetirei lá na frente o que narrei antes. Este livro sobre memórias nasce assim. Histórias săo recuperadas. Umas puxam outras. As histórias văo e voltam com mais detalhes e referências. Faço a releitura da releitura da vida da minha família. Reescreverei o que já escrevi (PAIVA, 2015, p.35).

Ainda estou aqui constitui-se, pois, como uma narrativa que funciona como um livro de memórias que náo exclui o caráter autobiográfico. Porque nâo se trata apenas das memórias de Marcelo Rubens Paiva, uma vez que esse autor nâo tem a intençâo de construir sua história ou autobiografia; há um deslocamento, na medida em que sua história pessoal é colocada à margem para dar lugar às histórias de seus pais. Portanto, temos um livro de memórias com traços autobiográficos que se apresenta em conformidade com as memórias reconstituídas e com o aspecto narrativo retrospectivo, organizada entre fatos narrados e comentários, por meio dos quais podemos perceber a presença de um autor-implícito no texto, que se encarrega de fazer "associaçôes e 
derivaçóes" (LEJEUNE, 2014. p.189) que promovem o estabelecimento de uma certa escrita da verdade.

A presença do autor-implícito se justifica pela maneira como a narrativa é tecida; com aspectos recorrentes da escrita ficcional. Ou seja, apesar de Ainda estou aqui se constituir como livro que apresenta características de memórias, de autobiografia e de escrita da verdade, a forma como o autor/narrador trabalha a narrativa năo deixa de ser uma construçâo, um espaço que comporta a noçăo de autor-implícito, bem como demais aspectos da chamada narrativa ficcional.

Wayne C. Booth (1980) sinaliza que cometemos um erro quando consideramos o autor, cujo nome consta na capa do livro, como o proferidor da narraçâo. Há sempre um trabalho de disfarce autoral, de distanciamento, entre a pessoa do autor e aquela voz que narra por ele, mesmo no caso de um livro de memórias ou até autobiográfico. Contudo, segundo Wayne C. Booth, "embora o autor possa, em certa medida, escolher seus disfarces, năo pode nunca desaparecer" (1980, p. 38), e essa intençăo năo passa de um disfarce ou de uma desculpa implícita, em relaçăo às quais devemos manter "a nossa capacidade de juízo irônico," (1980, p. 339).

Para esse estudioso, a ótica que organiza a narraçăo nâo é a do autor como convencionamos definir ou considerar, mas a da atuaçâo de outro, implícito. Mas, e no caso da autobiografia? A sugestăo mais aceitável é a de que cada narrativa comporta um autor-implícito, que pode ser diferente em cada obra, mesmo que de um autor biográfico único. Outra, tăo aceitável quanto, é a de que devemos inferir que, ao se vestir com suas memórias, o autor torna-se camaleáo para dar vazáo a um narrador detentor de todas as manifestaçôes verbais, uma figura que faz uso de uma máscara criada pelo narrador. O narrador passa a ser, por assim dizer, o bastante procurador do autor, com autorizaçâo para tomar toda e qualquer decisăo, para impor justificativas e dar o tom aos fatos narrados. Entretanto, os estudos sobre a retórica ficcional realizados por Booth sinalizam para além dessa imagem de narrador; segundo esses teóricos, trata-se de uma entidade capaz de se disfarçar e manipular a ótica da narrativa, bem como os demais elementos que auxiliam o leitor a compor uma ideia dos recursos narrativos; de modo implícito, esse autor "fez-se personagem dramatizado a quem reagimos como a qualquer outro personagem" (BOOTH, 1980, p. 228).

Dessa maneira, "o contar é em si uma representaçâo dramatizada do alter-ego do autor" (BOOTH, 1980, p. 228). Torna-se entăo mais fácil vislumbrar essa figura, por conseguir ultrapassar a noçăo de narrador, alguém camuflado pela ficçăo que năo consegue submergir o seu juízo, se isentar, no espaço do contar se inicia um novo ato; ao entrar em cena, o autor implícito se faz tăo poderoso quanto o narrador descrito anteriormente, porém incapaz de sufocar seus valores ou "apreciaçấo" por se tratar de uma categoria mais abstrata, que pode ser depreendida a partir das marcas textuais: daquilo que pode ser visto e daquilo que também é ocultado, do dito e do năo dito. Nesse caso, mesmo uma narrativa que se pretende memorialística ou autobiográfica comporta um autor implícito, que denota o trabalho de construçăo narrativa. Aqui, portanto, narrativa ficcional e biografia, memória, se encontram.

Ante a presença desse elemento retórico e fazendo relaçăo direta com Ainda estou aqui, as leituras e análises desse livro de memórias se coadunam na percepçăo de que ali estâo presentes mais de uma via de representaçâo autoral, através da escrita 
testemunhal, o aspecto de duplicidade é uma presença constante, por vezes bifurca e cumpre a função de perfazer as memórias:

\begin{abstract}
Por muitos anos, as traves em frente de casa mantiveram um rabisco que fiz na infância: MRP. Por muitos anos, fiz questăo de checar se o rabisco ainda se mantinha nas décadas de 70, 80. Mataram RP, mas o MRP resistia. Por alguma razáo que náo sei explicar a faixa de areia das praias cariocas encurtou. Minhas traves năo estăo mais lá. Levaram a madeira pintada de branco com o rabisco MRP. Reciclaram. RP e MRP năo resistiram ao tempo. Hoje há apenas redes de vôlei (PAIVA, 2015, p.123).
\end{abstract}

No caso do trecho acima, podemos inferir que o autor/narrador continua narrando e comentando: utiliza-se de um registro feito quando criança como metáfora para a vida que levava até a morte de seu pai, bem como os anos que passou tentando entender essa perda que provocou tantas mudanças. E comenta: "mataram RP, mas o MRP resistia". E com esse comentário, faz o tempo, nessa passagem das memórias, funcionar como um inimigo; que silenciosamente corrói o que aparentemente năo é corrosível. Insistir que com o passar dos anos a memória nâo se apaga é assistir a madeira com suas iniciais apodrecer, é lutar contra intempéries que săo inevitáveis, por isso, a ironia reside justamente no intercalar entre o resistir e o reciclar, imposto por novos acontecimentos, ou seja, nâo há remédio para os estragos causados pelas atrocidades de uma época e o tempo se encarrega de outra funçâo; preencher os vazios com resignaçăo: "Hoje há apenas redes de vôlei."

A narrativa de traço autobiográfico, nesse sentido, admite um autor implícito por ser uma projeçâo do autor dentro da narrativa, enfatizando a memória construída e estabelecendo o caráter duplo daquele que narra. E, nesse sentido, as escolhas narrativas sâo claras. O autor de Ainda estou aqui lança mâo de ferramentas retóricas para oferecer aos leitores todos os vieses da tragédia e lutas vividas por sua família durante o regime militar brasileiro, bem como as posteriores conquistas e respostas obtidas em tempos de democracia. Marcelo Rubens Paiva cria uma versâo implícita de si mesmo: o seu autor implícito.

Ao se colocar como autor implícito, o escritor impóe um limite; uma distância calculada e segura que o possibilita prosseguir com suas análises críticas e que o separa do narrador. É de se esperar, portanto, que através de suas articulaçōes ficcionais, seja o responsável pela narrativa, mas ao seguir com a leitura do (citado) livro de memórias, fica claro que naquele lugar narrativo há outras vozes. Apresenta-se, gradativamente, uma presença superior que conduz o leitor e domina todas as açóes.

Esse narrador, que se apresenta móvel, quase fluído, é o grande responsável pela completa recepçăo do leitor; sua flexibilidade temporal desenha o mapa que sinaliza suas intençóes, as (ditas) tensôes demarcam as personagens, compóem os significados necessários à planejada narrativa e, ao dominar todas as peças do tabuleiro romanesco, consegue, efetivamente, realizar sua avaliaçăo.

Através do narrador, o autor implícito provoca o leitor; suscita a repulsa às arbitrariedades de um regime autoritário, provoca a justa vibraçâo de vitória perante repostas que tanto custaram a serem dadas, ao mesmo tempo em que explora sua visăo e pontos de vista independente de qualquer suposto mal entendido, trata-se de "uma identificaçáo implícita entre narrador e leitor espectadores num momento de 
revelaçăo" (BOOTH, 1980, p.346). E tal identificaçăo se coloca como um impedimento para um necessário afastamento entre esses dois tipos retóricos, sendo assim, "mesmo que o autor e o leitor encontrem interpretaçôes divergentes, podem partilhar do sentido da realidade evocada" (BOOTH, 1980, p.347). Ou seja, uma partilha interessante porque nesse caso o narrador de Marcelo Rubens Paiva, ao deixar a narrativa para realizar comentários, de certo modo, torna-se leitor de sua própria narraçâo, assume a posiçáo que o leitor teria.

O problema ao qual nos propomos a discutir é distinguir, dentro do objeto de análise, os momentos em que esse autor constrói a narrativa e a maneira como narra. Por isso, é importante ressaltar que a presente análise procura investigar as marcas de um autor implícito justamente na articulaçăo entre narraçăo e discurso. Porque é na interpretaçáo dos sentidos existentes no embate entre o narrador que narra e o que comenta que se encontra a razăo ou ideologia da obra analisada e do seu autor implícito.

\section{A METANARRATIVA: 0 JOGO OSCILANTE ENTRE O NARRAR E O COMENTAR}

Antes de entrarmos na análise de Ainda estou aqui, consideramos interessante mostrar como o livro se encontra estruturado e, dessa maneira, realizar uma leitura mais próxima do texto de Marcelo Rubens Paiva. Assim sendo, começaremos pela compreensáo de sua macro organizaçáo: o livro está dividido em três partes enumeradas, sem apresentar título ou subtítulo.

A primeira contém cinco capítulos e, apesar da ausência de uma narrativa linear, segue uma cronologia, pois, a partir do segundo capítulo, o narrador revisita as origens da família do autor, sua infância, adolescência e juventude até a data do acidente que mudaria sua vida. O primeiro capítulo năo foge da funçăo de introduçâo e, por isso, apresenta as razóes para a escrita do livro: o nascimento do filho, o resgate da memória do pai e o drama da máe, acometida pelo Alzheimer, tudo isso perpassado pelo tom de crítica àqueles que na ocasiăo pediam a volta do regime militar e, por essa razăo, faz um verdadeiro alerta sobre a importância de se viver numa democracia.

Mais cinco capítulos dâo formato à segunda parte desse livro. É o momento da leitura em que conhecemos com detalhes a dor de uma família atacada pela ditadura militar. A prisăo e o desaparecimento de Rubens Paiva provocam a primeira grande ausência: a falta do pai. O que promove a reinvençăo de Eunice Paiva, que de măe e dona de casa, passa a ser o pilar de sustentaçáo para os filhos órfáos, principal provedora e exemplo de luta a ser seguido. A lacuna paterna faz com que esse pai seja reconstituído ficcionalmente em paralelo à reconstituiçăo realizada pelas investigaçôes da Comissâo Nacional da Verdade (CNV) e do Ministério Público Federal do Rio de Janeiro.

A terceira parte é o percurso final da narrativa, no qual somos provocados pelo narrador a comemorar as vitórias judiciais de Eunice, bem como as respostas que essa família buscou ao longo de décadas, além da descoberta e estabelecimento do Alzheimer no momento em que essa personagem começava a desfrutar da aposentadoria e o desfecho que nâo póe ponto final à narrativa.

Para comprovar o duplo movimento do narrador ao longo do livro de memórias, objeto dessa análise, retomamos Genette (1976), que define como narrativa aquela 
surgida no encontro ou na fronteira entre o discurso e a narraçăo. Pois bem, a narrativa de Marcelo Rubens Paiva, em seu Ainda estou aqui, inicia-se justamente pelo discurso (aspecto constitutivo da narrativa de primeira pessoa), em que evoca a memória justamente por meio de um comentário que atenta para a falta dela: "Năo nos lembramos das primeiras imagens e feitos da vida..." ( PAIVA, 2015, p.15). Esta é a sentença de abertura que o autor/narrador utiliza para convidar o leitor a acompanhá-lo através de uma escrita de cunho autobiográfico. Aquelas memórias que surgem quando somos crianças, com menos de três anos -momento em que ainda estamos descobrindo o mundo.

No entanto, à medida que vamos crescendo e desbravando a primeira infância, tal ausência vai sendo, gradativamente, substituída pelas recordaçóes que sáo armazenadas, confirmando a tese de que:

\footnotetext{
“Já temos MEMÓRIA desde o dia em que nos deram à luz. [...] Somos um pi-to-qui-nho de gente pe-ti-ti-ti-ca e temos memória, referências, jogamos com elas, calculamos nossas açōes nos apoiando em lembranças (já) solidificadas. No entanto, năo nos lembraremos de nada disso anos depois. As primeiras lembranças que guardamos para o resto da vida sáo as de quando temos três ou quatro anos, e a cada ano que passa virăo mais lembranças[...] 0 renascimento de um fato passado, seu reconhecimento e localizaçăo săo as condiçóes necessárias das lembranças" (PAIVA, 2015, p.16 - 17).
}

No entanto, só seremos capazes de recordar fatos e situaçóes que nos marcaram nesse período, a partir de testemunhos de familiares e, sobretudo, de registros fotográficos. Analisando Ainda estou aqui é possível perceber que uma cuidadosa teia é fabricada com o objetivo de oferecer explicaçôes para o nascimento de nossas memórias.

A escolha de narrar e comentar, do narrador de Marcelo Rubens Paiva, nesse começo da narrativa, se baseia no cruzamento entre o surgimento da memória do filho, com o gradativo apagamento das memórias de sua măe. Em outras palavras, ao realizar a oposiçáo entre memórias em diferentes momentos ou idades, o narrador (em Ainda estou aqui) se torna também personagem, por nâo conseguir se isentar, nem evitar de comentar ou dizer o que pensa. A partir dessa estratégia destaca-se a diferença entre lembrança e reminiscência e, assim, introduz o leitor no universo de quem tem um ente querido com Alzheimer.

Ao descrever o teste normalmente realizado para detectar se uma pessoa está sofrendo dessa doença, apresenta-se ao leitor a razăo pela qual vinha, até esse momento, discorrendo sobre como nossas memórias sâo construídas, como também explica um dos motivos que o levaram a escrever o livro objeto da presente pesquisa: o acerto de contas com a história e uma homenagem à sua mâe Eunice Paiva.

Ao usar a locuçăo verbal "deveria se sentir", ele fala de uma personagem real (Eunice), e como năo há, com exatidăo, a possibilidade de o narrador transferir-se para a subjetividade de sua mâe, a soluçâo mais viável é o emprego do discurso indireto livre. Assim, reproduz o que sua măe com Alzheimer supostamente estaria sentindo quando é levada para a audiência de interdiçăo judicial, articulando ficcionalmente, narra o episódio como se abrisse uma agenda antiga, ou diário de Eunice, para rever a data, o dia em que ela passou a ficar, oficialmente, à margem de si e dos outros. Ou seja, há nessa reproduçăo, uma tentativa de reconstruir uma memória praticamente perdida: 
Em nenhum momento ela perguntou o que estávamos fazendo, nem pediu para ir embora. Naquela fase, "passear", ver coisas e pessoas podia deixá-la feliz. E talvez ali se sentisse confortável. Restavam em sua memória os tantos momentos que esperou naqueles bancos. Minha máe deveria se sentir em casa por isso năo se queixava. Ainda havia algum senso de presente. Ainda. E talvez năo tenhamos UMA só memória." ( PAIVA,2015, p. 22 - 23)

No excerto acima, destaca-se a frase "E talvez năo tenhamos UMA só memória", indicando ao leitor que a memória de Eunice ainda estava ali, mas que em algum momento nâo existira e só restará a memória do narrado. E o narrador prossegue realizando idas e vindas temporais, de acordo com o fluxo ou mecanismos das lembranças, onde um fato rememorado remete a outro e outro, em um movimento nem sempre linear, através de alternâncias, terminando com uma ressalva para o que considera uma grande ironia, uma vez que há trocas de papeis entre a máe e o filho:

0 jogo tinha se invertido naquele instante. Em 30 de janeiro de 2008, naquela tarde abafada, na forma da lei no Foro Central Civil, na praça Joăo Mendes, s $/ n^{\circ}, 4$ andar, sala 426 do Tribunal de Justiça do Estado de Sáo Paulo, primeiro provisoriamente e depois definitivamente, aquela que cuidou de mim por quarenta e oito anos seria cuidada por mim. O referido é verdade e dou fé. Eu virara máe de minha máe. E năo choveu (PAIVA, 2015, p.29).

"Onde é aqui?" é o título desse (primeiro) capítulo, do qual o trecho acima foi retirado, faz referência a uma das perguntas recorrentes feitas por Eunice na fase inicial do Alzheimer e também pontua diversos momentos de sua vida; como o fato de ser interditada no mesmo foro civil onde por diversas vezes advogou, inclusive a favor do filho, e ajuda a ilustrar as contradiçóes da doença que afeta a coerência dos pensamentos, degrada a memória, em contraposiçăo à história dessa personagem que devido à viuvez (forçada) precisou se reinventar:

Uma memória nâo se acumula sobre outra, mas ao lado. A memória recente năo é resgatada antes da milésima. Elas se embaralham. Minha măe com Alzheimer năo se lembra do que comeu no café da manhă. [...] Foi advogada de ilustres e desconhecidos, foi consultora do governo federal, do Banco Mundial, da ONU. Para onde foi todo esse conhecimento? Está à deriva na sua memória, para lá e para cá, num mar de ligaçóes químicas de onde náo se enxerga o facho grande da costa, a grande fogueira, de onde se vê a terra, o ponto de partida. Como major Tom, de David Bowie que empacou flutuando no espaço, num jeito peculiar, ao redor da Terra (PAIVA, 2015, p. 23).

O trecho se inicia com um comentário sobre a possível organizaçăo e funcionamento da memória e, em seguida, narra um sintoma do Alzheimer, para logo depois provocar a oposiçấo com o brilhante currículo da paciente, o qual representa uma das muitas Eunices que o narrador viu nascer. Oposiçấo que ambienta a intromissâo: "Para onde foi todo esse conhecimento?". Aqui podemos verificar que o narrador se movimentou, saltou do comentário para o discurso e provocou uma interposiçâo entre essas espécies narrativas, pois, na sequência, retoma o comentário, dessa vez escolhendo o caminho metafórico ao citar uma música para concluir sua estratégia narrativa.

No capítulo seguinte, A água que nâo era mais do mar, Marcelo Rubens Paiva 
relembra o nascimento de seu primogênito, detalha a paternidade vivenciada durante o primeiro ano de vida do filho e retoma as hipóteses de náo nos lembrarmos do que vivemos nos primeiros anos refletindo: "Ele se lembrará disso no futuro?"(2015, p.32).

Como resposta, mergulha nas lembranças de sua própria infância revendo e comparando os anos iniciais na escola, os programas de televisáo que povoaram esse período, para cruzar com as (supostas) memórias do filho e os inexplicáveis lapsos de lucidez de sua măe que, nessa altura da narrativa, se encontra em estágio avançado do Alzheimer e, portanto, nâo deveria mais se conectar com suas memórias e experiências vividas, entretanto, consegue cantar músicas das quais gostava, sem esquecer nenhum trecho de letras como Aquarela do Brasil e Volare e sentencia:

A intensidade de uma lembrança é diretamente proporcional à sua antiguidade. As recém-chegadas somem antes daquelas de que lembramos muitas vezes na vida, as adquiridas. Quanto mais antiga e primitiva, mais estável ela é. As últimas se văo primeiro (PAIVA,2015. p. 34).

Aqui fica claro o quanto o autor-implícito se utiliza do disfarce de narrador fluído para descrever e comentar o movimento de ir e vir das lembranças que compóem uma memória; a narrativa retoma o nascimento de seu filho e tudo que se relaciona a esse dia chamado de milagroso, comparando a intensidade de um fato vivido com um quadro, que nada mais é que uma imagem perene nos corredores de nossa memória, o que muda é o nosso olhar. E pela primeira vez ele comenta o seu processo de escrita, como demonstra o trecho já citado anteriormente e que retomamos aqui:

Sei que repetirei lá na frente o que narrei antes. Este livro sobre memória nasce assim. Histórias săo recuperadas. Umas puxam outras. As histórias văo e voltam com mais detalhes e referências. Faço uma releitura da releitura da vida da minha família. Reescreverei o que já escrevi. (PAIVA, 2015, p. 35)

É nessa alternância que a narrativa segue para outra direçâo - entra na seara de outra razăo para a escrita de Ainda estou aqui - o desaparecimento de seu pai - para tanto, o autor (mascarado de narrador) reproduz um trecho da coluna escrita por Antonio Callado no jornal Folha de Sáo Paulo, na qual esse escritor relembra o encontro com Eunice em 1971, dias após esta ser solta da prisăo que se dera devido à acusaçăo de subversăo política do marido ex-deputado:

Outra ocasiăo que me ficou nítida liga-se a Búzios. Ali fui, num fim de semana de 1971, hóspede de Renato Ascher. Saíra com ele, Maria, Maurício Roberto e outros amigos para um passeio de lancha. Quando paramos, ao voltar, a uns cem metros da praia, vimos alguém, uma moça, que nadava firme em nossa direçăo. Minutos depois subia a bordo, cara alegre, molhada de mar, Eunice Paiva, mulher do deputado Rubens Paiva, amigo de Renato, amigo meu, de todos nós, um dos homens mais simpáticos e risonhos que já conheci. Eunice andara preocupada. Rubens fora detido pela Aeronáutica dias antes e nenhuma notícia sua tinha chegado à família. Mas agora Eunice, que fora também presa mas em seguida libertada, podia respirar, tranquila, podia nadar em Búzios, tomar um drinque com os amigos, pois acabara de estar com o ministro da Justiça, ou da Aeronáutica, que lhe havia garantido que Rubens já tinha sido interrogado, passava bem e dentro de uns dois dias estaria de volta a sua casa. 
Dois dias depois, isto sim, os jornais recebiam uma notícia tăo displicente que se diria que seus inventores náo faziam a menor questăo [de] que fosse levada a sério: Rubens estaria sendo transferido de prisăo, num carro, quando guerrilheiros que tentavam libertá-lo tinham atacado e sequestrado o prisioneiro. O que correu pelo Rio, logo que se suspeitou de sua morte, é que ele morrera às măos, ou pelo menos de tortura diretamente comandada pelo brigadeiro Joăo Paulo Penido Burnier, aquele mesmo que queria fazer explodir o gasômetro do Rio, para pôr a autoria do crime na conta dos comunistas. A família Paiva nunca mais teve notícias oficiais de Rubens. Nunca se encontrou a cova onde o terâo atirado depois do assassinato. A cara de Eunice continuou molhada e salgada durante muito tempo, tal como naquela manhá em Búzios. A água é que náo era mais do mar. (PAIVA, 2015, p. 35-36)

Ao fazer uso do texto de agosto de 1995, Marcelo Rubens Paiva reconstrói a provocaçăo feita (juntamente com sua măe) ao presidente Fernando Henrique Cardoso e ministro da justiça José Gregori (ambos amigos de seu pai), em artigo na revista Veja, sobre o silêncio para os atos cometidos pelos militares durante os 21 anos de ditadura, o paradeiro dos desaparecidos políticos, bem como as devidas satisfaçōes às famílias vítimas do mesmo trauma.

Essa reconstituiçăo tem dois objetivos: primeiro ao leitor é apresentado o descaso dos governos pós redemocratizaçăo para com essa problemática, e segundo, o sentimento de vitória e reparaçâo, uma vez que a repercussăo do artigo, escrito por um filho de desaparecido e conhecido escritor, foi tăo grande que culminou na promulgaçâo da Lei 9140 de 4 dezembro de 1995 que, com o tempo, passou a ser chamada de Lei dos Desaparecidos, por reconhecer como mortas todas as pessoas que possam ter desaparecido em razâo de participaçáo de atividades políticas entre 02 de setembro de 1961 a 15 de agosto de 1979. Porém, esse narrador náo comemora, pelo contrário, năo consegue se afastar do trauma vivido, é ácido e desafoga: "Meu pai, um dos homens mais simpáticos e risonhos que Callado conheceu, morria por decreto, graças à Lei dos Desaparecidos, vinte e cinco anos depois de ter morrido por tortura" (2015, p. 38).

A Lei 9140 atesta como mortos todos aqueles desaparecidos que praticaram atividades políticas, por isso, com a sua vigência, as famílias de desaparecidos políticos no período do regime militar puderam receber o atestado de óbito, bem como requerer indenizaçăo à Uniăo. Para a família Paiva, essa foi uma vitória após mais de duas décadas de uma versâo oficial fantasiosa que declarava o ex-deputado como fugitivo e impedia que sua esposa pudesse se considerar viúva legalmente. Trata-se de uma vitória que se tornou um marco entre as diversas batalhas enfrentadas por Eunice Paiva nos vários anos em que buscou respostas: "Ela ergueu o atestado de óbito para a imprensa como se fosse um troféu. Foi naquele momento que descobri: ali estava a verdadeira heroína da família; sobre ela que nós, escritores, deveríamos escrever" (2015, p. 38).

Eunice esteve presente na cerimônia de promulgaçăo daquela que ficou conhecida como Lei dos Desaparecidos, sentando-se entre o presidente da república e o general chefe da casa militar, no encerramento, seguindo o protocolo, cumprimentou a ambos. A imagem de uma vítima da ditadura abraçando um militar reforçou o argumento da família Paiva de năo ter querido revanche, mas justiça; no entanto, năo impediu que o narrador concluísse o capítulo agradecendo (ironicamente) aos militares por náo terem assassinado sua măe, ou seja, nâo é apenas o emprego de sarcasmo, mas também é 
o emprego de uma narrativa onde "sem serem estanques, as duas situaçóes de locuçóes narrar e comentar se interpenetram" (NUNES, 2003, p. 40).

Na sequência, chegamos ao capítulo Blá, blá, blá..., expressăo que năo apenas intitula a terceira divisão de Ainda estou aqui, mas umas das mais proferidas por Eunice para registrar sua irritaçăo quando acometida pela confusáo de pensamentos. Isso serve como disparador para um recuo nas lembranças, pois, nesse momento do livro, Marcelo Rubens Paiva também se dedica a rever suas origens - de como seus avós maternos migraram para o Brasil e se fixaram no Brás, o cotidiano de uma família tipicamente italiana e o quanto sua măe destoava nesse cenário, porque segundo ele, "a única pessoa nâo cem por cento italiana da famiglia era justamente a minha máe."(2015, p.43) De sangue, de fato, Eunice era da famiglia, mas de alma muito pouco, diz Marcelo Rubens Paiva, visto que desde cedo ela foi de encontro às regras impostas, tanto que entrou na faculdade de Letras do Mackenzie, em primeiro lugar, aos dezoito anos, contrariando os planos de casamento de seu avô. Um pouco antes, é narrada a mudança da família materna para Higienopólis, o ingresso da măe no colégio Sion e a amizade com uma Paiva, que mais tarde se tornaria sua tia, a partir de entâo, relembra sua relaçấo nada convencional com Eunice e desabafa: "me pergunto se é normal um cara invejar a mâe dos outros. Passei a vida achando minhas avós, tias e măes de amigos mais afetivas que minha máe. [...] Minha măe deve ter me dado uns quatro beijos na vida." (2015. p.44)

O narrador (autor) náo hesita em reclamar do quanto a praticidade de sua măe o incomodava: "era culta, magra, sensata e workaholic. Tudo o que năo se quer de uma mâe." (2015, p. 44), e dialoga com o leitor sobre o uso do tempo passado para esclarecer o quanto é difícil ter um ente querido com Alzheimer, aceitar que este está presente, mas năo está, tanto que ao detalhar a expressâo comumente repetida por Eunice: blá, blá, blá, faz um contraponto para a conclusăo de que, apesar de ter lido muito, de ter sido prática, organizada e excelente profissional, com a demência nada disso teve serventia: năo passa de uma grande piada de mau gosto realizada pelo destino.

E assim, quando pensamos que o capítulo está terminando, nos é apresentada a família (paterna) Paiva, e o autor de novo recua, volta no tempo para rever as férias de sua infância com irmăs, primos e primas na fazenda do avô em Eldorado Paulista. Período em que se sentiu "uma das crianças mais felizes do mundo" (2015, p.55), para na sequência comentar a trágica mudança iniciada com a prisâo de seu pai e a oposiçâo a essa felicidade:

Porém a cortina se abriu e começou o segundo ato do espetáculo, que até entăo era uma farsa, mas se revelou uma tragédia. Meu pai desapareceu em 1971, no mesmo ano em que morreu meu tio mais velho, Carlos. Meu avô morreu dois anos depois. De enfarto. De tristeza. Logo depois outro tio morreu num acidente de carro na estrada que ligava a fazenda a Săo Paulo. Um terremoto abriu uma fenda. O sentido de tudo se modificou. Nos perguntamos o que alimentou uma vingança tăo caprichosa e cruel. O que fez os deuses da felicidade se voltarem contra nós. Morreu uma prima, a mais animada, năo tinha dezoito anos, de uma doença misteriosa. Depois outro primo, um menino lindo, num acidente de moto em Santos. A tragédia dos Paiva foi um contraste com a alegria de décadas anteriores. A família ruiu: năo tinha estrutura emocional para administrar tudo aquilo (PAIVA, 2015, p. 55-56). 
Há nesse trecho questionamentos que ajudam na reconstruçăo da memória, por elencar cada acontecimento que descortinou uma infância até entăo plena e introduziu anos de choro, perseguiçôes e dúvidas. Podemos perceber que a compreensâo da figura do autor implícito como uma forma de realizaçăo ficcional se confirma - as instâncias narrativas - os chamados modos ou pontos de vista, bem como as ditas vozes, tanto do narrador quanto dos personagens comprovam as açôes consideradas autorais. E é com o mesmo peso que a problemática do Alzheimer é sobreposta, como se para enfatizar que apesar dos consequentes avanços e vitórias, a vida dos Paiva seguiu pela lógica da incompreensáo - a partir de outra estratégia - a de convencer o leitor através das várias maneiras de se (re)contar um acontecimento.

Qual o sentido para esse movimento? Como o próprio título diz, trata-se de cometas da memória - momentos que remontam a fatos marcantes rememorados fugazmente. E faz jus à rápida estratégia que o autor utiliza para retornar aos anos que antecederam a tragédia sofrida pela sua família - o desaparecimento de Rubens Paiva. Após ser cassado em 1964 pelo ato institucional número 1 (AI -1), o ex-deputado parte para o exílio, de onde, depois de alguns meses, retorna clandestino e resolve, em 1965, se mudar com a família para o Rio de Janeiro: "Ele fugia do estigma de paulista comunista inimigo da ditadura. [...] Imaginava ter menos visibilidade e mais oportunidades na Guanabara" (2015, p. 64). A reconstituiçâo dos fatos que ocasionaram a perda dessa família reforça a presença do autor implícito que se comporta como narrador para falar em nome de Marcelo Rubens Paiva e, dessa forma, poder ser protagonista, testemunha e (excelente) comentador. Trata-se de um momento em que a narrativa, assim como um cometa, rapidamente se alterna entre a objetividade e a subjetividade, ao passo que refazem, ainda que como lampejos, as memórias daquele período.

Trata-se de um período que para o menino Marcelo foi um tempo de rápida adaptaçâo: "a vida no Rio, diferente de Săo Paulo, era na rua e na praia. Empinando pipa e jogando bolas de gude nos canteiros de terra do Leblon" (2015, p. 67), ou seja, foi um tempo em que fez amigos na rua, teve total liberdade para perambular pelas vizinhanças, apesar de morar próximo a comunidades pobres, naquela época năo existia os temores do presente. E um momento de recordar as descobertas, às escondidas, como único garoto da casa, do universo feminino da măe e irmăs, descrever a tentativa de recomeço do pai que se associa em uma pequena firma de engenharia e passa a trabalhar como nunca, inclusive em fundaçóes de novos condomínios que acabaram sendo destinados a militares, (outra grande ironia), das novas amizades no colégio, ou seja, um cotidiano como o de qualquer criança dos anos sessenta. Entretanto, quando tudo parecia calmo e restabelecido, a interceptaçăo (pelos órgâos de repressâo) de correspondência vinda do Chile endereçada a Rubens Paiva provocou sua prisăo, a falta de notícias e incertezas que levaram a família a mais uma mudança de cidade: sua măe, a partir desse episódio se viu sozinha e, sem notícias do marido, resolveu se mudar com os filhos para Santos, onde vivia a família do esposo.

É na casa dos sogros que Eunice inicia sua reinvençăo quando, apesar da imensa tristeza, como dito anteriormente, volta a estudar, presta vestibular para direito, é aprovada e já convencida de que é uma viúva, novamente resolve se mudar com os filhos e retorna para Săo Paulo onde empreende uma luta que durará décadas: a busca sobre a verdade sobre o paradeiro do marido. A partir de entâo, deixou de ser uma esposa 
e mâe de sua época, passou a ser arrimo de família, tornou-se o que Marcelo Rubens Paiva considerou como máe protocolo, uma vez que, como diz: "nunca foi a uma reuniâo de pais e mestres nas escolas em que estudei depois de ter ficado viúva aos quarenta e um anos. Tinha mais o que fazer. Confiava no bom senso das escolas e delegava aos cinco filhos a missâo de zelar pela própria educaçăo" (2015, p. 73).

Como o próprio título indica, esse (quinto) capítulo é dedicado à sua relaçăo com Eunice enquanto atravessava a adolescência e se tornava jovem adulto: a cumplicidade diante dos seus atos de rebeldia, a distinçâo de tratamento dada ao único filho homem, traços de uma educaçâo de sua geraçâo cujas mâes podem ser consideradas machistas, ao passo que ensinou esse mesmo filho a ser delicado com as mulheres. Mesmo ressaltando sua constante perplexidade por năo ter uma măe convencional, o autor imprime, em cada circunstância rememorada, tons de admiraçăo e compreensâo que parecem sedimentar a homenagem que tece, a cada divisăo das memórias, a essa mulher cuja biografia está ameaçada de (a exemplo de muitas heroínas anônimas) desaparecer.

"Mâe-protocolo" encerra a primeira parte das memórias e aparentemente coincide com mais um episódio trágico para essa família: o acidente sofrido por Marcelo Rubens Paiva, aos vinte anos, que o deixa tetraplégico, episódio que pode ser considerado mais um divisor de águas para esses dois personagens, mas ele despista: "aí já é outro livro." (2015, p. 86)

Antes de encerrar essa sessăo, faz-se necessário alguns apontamentos; ao longo dessa primeira parte de Ainda estou aqui, os padróes narrativos foram parecidos e o impacto desses na narrativa pode ser explicado pelo jogo da alternância entre discurso e narraçáo. Marcelo Rubens Paiva, ao revisitar suas memórias, escolhe fazê-lo pela perspectiva do filho que reconstitui a figura do pai de maneira íntima, distanciando-se da figura histórica de mártir da ditadura, humanizando-o - consegue criticar suas escolhas, emociona o leitor ao chamar de coitado o homem que já fora seu herói - e, ao emocionar, trazendo o leitor para perto, eliminando distâncias.

A segunda parte do livro se inicia com uma contextualizaçâo histórica sobre a deposiçăo do presidente eleito pelo voto popular, Joáo Goulart, a instituiçấo de um regime militar que forjava ser revolucionário e, por isso, cumpridor dos direitos previstos na constituição. Ao descrever com riqueza de detalhes esse acontecimento, o narrador persegue outro dos motivos para a escrita das memórias de sua família: o desconhecimento histórico das novas geraçôes que levou alguns grupos, em 2014, a irem às ruas pedir a volta dos militares ao poder. O capítulo é intitulado Merda de ditadura, para enfatizar que essa náo serve para nada, que se trata de um modelo de governo arbitrário, um retrocesso para qualquer sociedade, e, como alguém que testemunhou, que sentiu na pele a truculência desse período, revisa todos os motivos que foram usados como justificativa para a derrubada de um governo democrático, a ascensăo e permanência das forças armadas no poder por mais de duas décadas, a ausência das liberdades, bem como a instituiçâo de um sistema repressor como política de estado que acabou caracterizando o regime inicialmente chamado de revoluçăo.

Assim, o narrador começa essa segunda parte das memórias relembrando a renúncia do presidente Jânio Quadros, em 1961, no momento em que seus pais se encontravam de férias em Moscou. O jovem engenheiro e sua esposa retornam ao Brasil, por idealismo e mesmo sem o apoio de Eunice, Rubens Paiva decide se candidatar a deputado federal, é eleito em 1962 e cassado em 1964, sendo obrigado a se refugiar na 
embaixada da Iugoslávia e depois se retirar do país.

Trata-se, portanto, de uma reconstituiçâo do período histórico onde săo descritas as práticas de um regime que perseguia qualquer um que fosse contrário aos seus princípios e as tentativas de resistência que foram possíveis diante do desigual aparato militar e emprego de força. Nesse cenário de imposiçôes e, a partir de um trecho de uma cançấo popular alemă; "O, du lieber Augustin, alles ist hin...Oh, querido Agostinho, tudo está perdido" (2015, p.113). Marcelo Rubens Paiva reconstitui os fatos que possivelmente levaram à prisâo e morte de seu pai. É a peste Augustin - perdâo tenho que morrer é um dos capítulos em que mais acontece o misto entre reconstituiçâo e comentário. Ou seja, o referido aspecto duplo da narrativa, que ora esforça-se por instaurar o passado por meio de um trabalho ficcional, ora envereda por comentar esse próprio trabalho de reconstruçâo da memória, que passa inevitavelmente pelo esforço ficcional. Assim, no trecho abaixo, podemos verificar um exemplo complexo dessa tentativa de recriar um passado, em especial a memória do pai do autor, por meio de uma técnica narrativa que passa pela estratégia de o narrador em terceira pessoa dar espaço à própria voz de seu pai, que passa a narrar em primeira pessoa. Vejamos:

\footnotetext{
Năo tenho palavras, Eunice, Verinha, Cuchimbas, Lambancinha, Cacareco, Babiu... Perdăo. Nâo verei mais vocês crescerem, năo estarei mais ao lado de vocês, năo consigo mais proteger vocês, năo vou mais brincar com vocês, escutar suas risadas, correr atrás, nadar, năo acompanharei vocês na escola, nossa casa maluca năo sairá do papel, năo saberei que faculdade farâo, que diploma pegarăo, năo acompanharei vocês na vida profissional, năo conhecerei seus filhos, meus netos, năo verei meus netos crescerem, năo estarei ao lado deles, năo os protegerei, năo vou brincar com eles, escutar as risadinhas, correr atrás, nadar, năo acompanharei eles na escola, e como é triste saber que tudo isso acaba, que meu momento com vocês foi tăo curto, que năo pude aproveitar mais, que triste que năo posso ficar, năo me deixam ficar, é inevitável que eu vá, eu năo queria, eu náo queria, estou tăo triste. Tenho que morrer agora. Morreu repetindo seu nome. Meu nome é Rubens Paiva, meu nome é Rubens Paiva, meu nome é Rubens Paiva, meu nome é Rubens Paiva, meu nome é Rubens Paiva, meu nome é Rubens Paiva... (PAIVA, 2015, p. 108-109).
}

Sendo assim, há momentos em que năo se trata apenas da relaçăo entre narraçáo e comentário, mas sim da questâo de o narrador, aqui, assumir (ficcionalmente) a consciência de seu pai, de modo que quem narra, aqui, em primeira pessoa, é o pai, diretamente, é como se Marcelo Rubens Paiva emprestasse sua "voz" para o seu pai poder dizer aquilo que talvez pudesse dizer depois de morto ou estivesse dizendo ou pensando enquanto agonizava nas máos dos carrascos durante a tortura. Aqui o caráter ficcional (de criaçáo) é fundamental para imprimir um caráter impactante da narrativa, produzir um efeito realista, diria, só que com o recurso da criaçâo. O mais interessante é que, ao final, o único momento do trecho citado em que Marcelo Rubens Paiva assume a voz novamente é "Morreu repetindo seu nome". Ou seja, é a voz do narrador (em $3^{a}$ pessoa) introduzindo a fala (suposta) de seu pai "Meu nome é Rubens Paiva". O que veio antes poderia ser considerado como discurso indireto livre, já que se trata de uma narrativa do suposto pensamento de seu pai. No final, a sobreposiçăo é ainda mais marcada, pois a frase "Meu nome é Rubens Paiva" pode ser dita tanto pelo pai quanto pelo filho. Isso revela um sentido para esse modo narrativo: o quanto o pai năo é, inevitavelmente, uma criaçăo sua, por necessidade. 
Se no exemplo acima podemos reconhecer um autor implícito manejando a alternância entre narrativa em primeira pessoa e em terceira a fim da criaçăo de um efeito realístico para as memórias que procura reconstruir; no trecho abaixo, vemos o mesmo narrador distanciando-se do caráter narrativo e inserindo o questionamento acerca da identidade da personagem a quem deu voz, o seu pai:

Quem era meu pai? Por que a tortura foi tăo violenta? Falo de décadas de mistério. O que aconteceu, como? A imprensa, com o tempo, com o fim da censura passou a trazer histórias, depoimentos. Quando Brizola foi eleito governador do Rio, iniciou uma grande escavaçăo no Recreio, para achar a ossada supostamente enterrada lá. Foram meses de escavaçáo em 1987, depois que Nilo Batista, secretário de Segurança, recebeu uma carta anônima. (PAIVA, 2015, p.217)

Aqui, o caráter dual da narrativa aparece de modo bastante evidente: o narrador em primeira pessoa (agora o próprio porta voz do autor) coloca acerca de seu pai, da tortura, do mistério que procura desvelar e que, de certo modo, recriou por meio de suas estratégias ficcionais mencionadas acima quando assume a voz de seu pai. $\mathrm{O}$ trecho inicia-se por meio do discurso marcado; trata-se, pois, do comentário do narrador acerca dos fatos que procura conhecer. Na sequência, o narrador assume a empreitada de reconstruir o passado, rememorando fatos históricos, permeados, inclusive, por elementos objetivos, como a citaçăo de datas e de nomes de personagens históricos. É relevante levar em consideraçăo o poder exercido pelo discurso sobre a narraçấo, já que o eu, que profere o discurso, carece de uma história que ele sabe que existiu, mas sobre a qual náo tem a certeza, ou pelo menos se apresenta intocada. O poder ou a ascendência de um sobre o outro se verifica nesse impasse; na contaminaçăo da narrativa pelo discurso e vice-versa.

$\mathrm{O}$ ato de comentar faz parte do jogo de alternância discursiva desempenhado pelo autor-narrador para manter o leitor próximo do seu ponto de vista, para trazê-lo consigo, reafirmando sua funçâo de exímio comentador. Assim, no capítulo intitulado É a peste, Augustin - Perdăo, tenho que morrer é possível verificar essa característica de modo bastante marcado:

A memória é uma mágica năo desvendada. Um truque da vida. [...] $\mathrm{O}$ que mais lembram dele? Da gargalhada, que fazia tremer a casa. Fumava charutos. Gostava de comer do melhor. Gostava de viajar. Gostava de Paris. Chegou a morar lá, aos vintes anos, a uma quadra do Sena. Passou um ano na Europa, com os três irmáos, em 1947, para testemunhar a reconstruçáo de uma terra arrasada. Falava inglês e francês. Cantava algumas músicas em alemáo, que aprendeu com sua tia Berta, alemá solteirona: “O, du lieber Augustin, Augustin, Augustin. O, du lieber Augustin, alles ist hin..." Oh, querido Augustin tudo está perdido...Música austríaca baixoastral cantada de forma histriônica, como toda música em alemáo, que fala da quase destruiçăo de Viena pela peste no final do século XVII. [...] Imaginar esse sujeito boa praça, um dos homens mais simpáticos e risonhos que muitos conheceram, aos quarenta e um anos, nu, apanhando até a morte...é a peste, Augustin. Dizem que ele pedia água a todo momento. No final, banhado em sangue,repetia apenas o nome. Por horas. Rubens Paiva. Rubens Paiva. Ru-bens Pai-va, Ru...Pai. Até morrer (PAIVA, 2015, p.112 - 113). 
Aqui, no início do trecho, o narrador questiona-se, por via do comentário, sobre a natureza da própria memória para, em seguida, apresentar uma reconstruçăo da memória de seu pai, a qual, de certo modo, apesar de ser matizada por um aspecto bastante pessoal, pois se trata de um filho lembrando de seu pai, é apresentada como se fosse uma memória coletiva, ao se convocar: "O que mais lembram dele".

Na sequência, o narrador evoca, por meio de uma narrativa em sumário, uma série de qualidades e de características de seu pai, no sentido de imprimir um caráter realisticamente humanizado a ele para, por fim, retomar o momento crucial de sua tortura e morte. $O$ trecho se encerra, tal como o anteriormente citado, com a voz do pai repetindo o seu nome, antes de morrer. A repetiçăo reiterada de falas e de acontecimentos acaba por proporcionar um fortalecimento do caráter realista de uma memória que se faz, agora, mais evidente, porque criada pelo narrador, de modo que a própria narrativa acaba se constituindo como uma resposta propositiva para as perguntas que se coloca, de modo que acaba por colocar em prática aquilo que descreve em seu comentário inicial: "A memória é uma mágica năo desvendada. Um truque da vida". A memória, nesse momento, parece se configurar como uma mágica năo desvendada da ficçâo, um truque contínuo da narrativa.

Essa continuidade está presente em vários momentos da narrativa, a exemplo do trecho retirado do capítulo seguinte - $O$ telefone tocou - em que o narrador comenta:

A memória năo é apenas uma pedra com hieróglifos entalhados, uma história contada. Memória lembra dunas de areia, grâos que se movem, transferem-se de uma parte a outra, ganham formas diferentes, levados pelo vento. Um fato hoje pode ser relido de outra forma amanhá. Memória é viva. Um detalhe de algo vivido pode ser lembrado anos depois, ganhar uma relevância que antes náo tinha, e deixar em segundo plano aquilo que era entăo mais representativo. Pensamos hoje com a ajuda de uma parcela pequena do nosso passado. A prisăo de meu pai (como a de minha măe e da minha irmă) com o tempo ganhou outro significado, outras provas, testemunhas, releituras. (PAIVA, 2015, p.117)

Por que é importante falar da memória como algo móvel? Ao elencar as possibilidades de se registrar a memória, o narrador refaz os anos que se passaram desde a prisáo do pai como se para explicar que apesar de terem desaparecido com o corpo, de terem tentando de todas as maneiras apagar o seu legado, de se esforçarem para o seu total esquecimento, Rubens Paiva foi gradativamente sendo lembrado.

O que no início afastava as pessoas, conhecidos, familiares, por medo de serem associadas à subversâo e sofrerem represálias, vai mudando com a abertura política, o processo de redemocratizaçăo, a devoluçáo das liberdades e outras leituras foram possíveis. Ele deixa de ser uma ameaça para a segurança nacional, deixa de ser um terrorista perigoso com contatos no exterior, para se tornar umas das muitas vítimas do autoritarismo que vigorara no Brasil, sua imagem é refeita, assume feiçōes de idealista morto por uma causa nobre. Como se deixasse de ser um retrato entalhado numa rocha, para ser imortalizado pela oralidade que resiste através das geraçóes.

Esse movimento, essa mudança de um lugar para outro dos fatos, que com o tempo podem ser revistos, também ocorre com a biografia de sua máe. Ao comentar a natureza da memória, o narrador chama a atençăo para a impossibilidade de se conceber um 
fato passado como algo congelado, cristalizado, fóssil que só contasse do seu tempo, porque a memória pulsa, vibra e sempre pode ser relida através de novos testemunhos, documentos, e no caso de Ainda estou aqui, recontada a partir de elementos retóricos presente na ficçăo.

Para esse narrador, os anos da infância vividos no Rio de Janeiro foram os melhores, todos estavam adaptados, cheios de planos, mas de repente, numa manhă de sol, dia em que todos deveriam ir à praia, o insólito aconteceu: "O feriado de 20 de janeiro de 1971 é um dia que náo tem fim. Demoramos para entender porque esse dia existiu e foi daquele jeito" (2015, p. 115). Aqui fica claro; a reconstituiçâo da memória é feita através de recursos da narrativa comprovada pelo emprego do pretérito perfeito "demoramos". A presença desse verbo sugere que o narrador fala de si, mas também de sua família, ou seja, ele reconta se aproveitando da maleabilidade entre o narrar e o comentar.

Trata-se de um capítulo no qual o narrador refaz os acontecimentos a partir da perspectiva de um menino de onze anos que tentava entender aquele estranho feriado, um dia que mudou tudo. Mas, o recuo no tempo para encontrar o Marcelo Rubens Paiva menino é concluído e temos no presente um narrador que se angustia, questiona: "O que vemos náo é bem o que vemos. Por isso, como muitos, escrevo o que já escrevi" (2015, p. 125). E prossegue, cunhando a próxima seçăo do livro: Doze dias.

Esse é o momento de redirecionar a narrativa para Eunice, afinal ela é quem assume a família depois daquele dia de Sáo Sebastiâo. Para começar, é presa no dia seguinte, 21 de janeiro de 1971, por doze dias é mantida em total isolamento, prestando depoimentos que pareciam nâo fazer sentido. Diante dessas detençôes e com medo de que seus filhos também fossem levados para "esclarecimentos", a família esconde as crianças em diferentes esconderijos.

O narrador vai percorrendo, entâo, uma suposta investigaçấo mental operada por sua măe, entăo no cativeiro. Em seu isolamento, começaria a montar um quadro com as lembranças dos momentos com Rubens Paiva, com os vários amigos que frequentavam sua casa e relacioná-los às fotografias que era obrigada a ver, com o objetivo de reconhecer alguém, de ajudar em outras prisōes.

Em silêncio, juntava nomes, rostos e tentava entender porque tudo aquilo estava acontecendo até concluir que seu marido mantinha ligaçōes com ex-presos políticos exilados, que colaborava com dinheiro com alguns em situaçăo de clandestinidade, ajudava a esconder, a sair do país.

Meu pai sabia desse sequestro. Meu pai sabia intimidades desse sequestro. Quando noticiaram pela tv a demora e o sofrimento que o diplomata deveria estar passando nas máos de terroristas ele debochava: - Tá nada, está se divertindo adoidado, fumando seus charutos. Minha mâe reparou, foi a primeira e única vez que meu pai falou de algo que ocorria nas entranhas da luta armada (PAIVA, 2015, p.136).

No trecho acima, Marcelo Rubens Paiva narra em primeira pessoa reconstruindo um fato que năo vivenciou, que soube depois, que ouviu sua máe relatar, e em dado momento "se retira" para dar lugar a um comentário feito por seu pai. O movimento se conclui quando a narrativa volta para primeira pessoa. A alternância de vozes narrativas 
só é possível pela (re)criaçăo ficcional que permite que a narrativa se desloque para além do cruzamento entre o narrar e o comentar produzindo efeitos significativos para a interpretaçāo dessas memórias.

O tom irônico é uma constante em Ainda estou aqui, por vezes já o detectamos nos títulos escolhidos para cada capítulo, noutras na acidez sempre presente nos comentários do narrador. Ou, ou, ou, ou, ou năo foge a essa regra - esse foi um refrăo muito difundido nos anos do governo Médici que enaltecia os feitos do (contestável) milagre econômico.É nesse cenário de propagandas enganosas que começa a luta de Eunice para elucidar o desaparecimento de Rubens Paiva nos meses que sucederam a sua soltura. Conforme nos relata o narrador, ela bateu à porta de todas as instâncias jurídicas a que teve acesso, procurou políticos, falou com ministros sem nenhum sucesso.

O labirinto de contrassensos que minha măe começou a percorrer era longo.[...] Onde ele estava? Quem poderia nos ajudar? Era o Brasil do AI-5.[...] Cinco meses se passaram e nada. Callado testemunhou: minha mâe já esteve tranquila. Buzaid, o próprio ministro da Justiça, também de Santos, também despachante aduaneiro, como meu avô paterno Jayme Paiva, colegas de ofício, garantira que meu pai seria solto. Seu marido sofreu alguns arranhōes, dona Eunice, está se recuperando e será solto logo, logo. Só no final de junho ela recebeu uma carta escrita à măo da professora das minhas irmâs, Cecília, que reconheceu no álbum de fotografias do DOI. Ela estivera presa com meu pai. E decidiu contar o que aconteceu. Só entăo o quebracabeça começou a ser montado. E Poliana parou de sonhar (PAIVA, 2015, p.158).

Eunice năo só parou de sonhar, como também parou de sorrir por muitos anos. Como já mencionado em outro momento da narrativa, ao se perceber sozinha e sem nenhum progresso quanto ao paradeiro do marido, decide ir morar com os sogros em Santos. E esse período é batizado pelo narrador como $O$ sacrifício, um capítulo dedicado às lutas da mâe; sâo páginas que refazem o período que antecedeu a abertura política no qual retoma os primeiros anos após a prisâo de seu pai, a mudança para a casa dos avós paternos, o levantar do châo de Eunice que conduz a volta da família para Sáo Paulo em 1974, dá um salto temporal e termina em 2014 com a reproduçâo das investigaçóes realizadas pela Comissăo Nacional da Verdade (CNV) e o Ministério Público Federal do Rio de Janeiro que elucidaram o caso Rubens Paiva.

Assim, podemos indicar que o sentido do aspecto metanarrativo em Ainda estou aqui reside no desejo do autor em tornar verídicas memórias reconstituídas. Para tanto, se utiliza de aspectos da retórica ficcional para, a partir de fragmentos, preencher as lacunas biográficas do pai, dessa maneira é possível perceber, em diferentes passagens do livro de memórias, a presença de uma autor-implícito conduzindo alternâncias e sobreposiçôes narrativas que configuram o fenômeno da metanarraçăo.

Os modos de reconstituiçăo da memória em Ainda estou aqui verificam que narraçâo e metanarraçâo confirmam as inúmeras possibilidades de estratégias que resultam no ato narrativo: podemos nos aproximar da história de Marcelo Rubens Paiva quando seu narrador é testemunha e podemos nos afastar quando no seu processo de criaçấo literária ele dá voz ao pai, por vezes supooe o pensamento da mâe, questiona identidades para reforçar nossa crença no personagem homenageado. Todos os manejos săo de um narrador em constante deslocamento, que, ao se movimentar, nâo se aparta da dor, se 
esforça para que sua narraçăo seja realista e dessa forma mantém o leitor ao seu lado nas fissuras dos traumas revividos e esse talvez seja o grande saldo interpretativo para o caráter metanarrativo dessas memórias.

"Nascia uma nova Eunice. Renascia uma família" (2015, p.182). Aqui o narrador relata o caminho que cada um trilhou após o desaparecimento de Rubens Paiva. Em Depois do luto é narrado o empenho de Eunice para se inserir no mercado de trabalho, educar os cinco filhos, se reerguer financeiramente, em um tempo que năo podia provar sua viuvez e acessar os bens de família. Aos poucos, cada filho foi encontrando seu caminho, a exemplo do que viam em casa, assim como é descrito no trecho:

Chegou a hora do vestibular, eu tinha que escolher a carreira no formulário da Fuvest, um X nas várias opçōes, um X para o resto da vida. [...] Mas eu era o único homem da casa, năo um moleque qualquer, eu tinha responsabilidades, tinha que cuidar delas, e năo tem discussăo. Meu pai também foi meu modelo. Imitá-lo era uma missáo. Ser como ele, ter sua integridade, seu carisma, inúmeros amigos, prestígio, uma profissăo que incluísse viagens. Olhava para minha măe e deduzia que ela me preferia um filho engenheiro como o marido, com chances de obter um bom patrimônio no futuro, ajudar nas finanças abaladas da família, que vivia hoje sem saber do amanhá. Com os amigos dele, eu teria emprego garantido em grandes firmas, companhias de engenharia, empreiteiras. Quem sabe até herdar o espólio deixado por ele, reconstruir sua firma, reassumir seus projetos, sua vida. Tá, engenharia! (PAIVA, 2015, p. 186 ).

Também podemos verificar que o trecho narrado em primeira pessoa sinaliza para mais um cruzamento entre as estâncias do narrar e do comentar, uma vez que o autor tem profundo conhecimento dos fatos e somente (re)contá-los nâo é suficiente, o ato de comentar năo é isolado, traz para a narrativa profundidade - atesta o quanto a memória é fluída, carregada de estratégias, que se colocam a favor do processo metanarrativo - o passado é trazido para o presente, reconstruído pelo autor implícito que se revela em parte como narrador. No trecho acima, novamente acontece uma atividade narrativa em série, ou seja, é o discurso que reprisa, elenca, descreve uma memória permeada de traços autobiográficos.

E esse cruzamento ou movimento do narrador continua:

Fui para a Escola de Comunicaçăo e Artes da USP. Minha măe năo se opôs. Ganhava um bom dinheiro como advogada. Minhas irmás, no mercado, na vida. Sustentavam-se. 0 mais fodido e perdido era justamente eu, o moleque, o único homem da casa. Quem sabe eu náo faria aquilo que meu pai sempre quis: dirigiria um jornal. Como ele, que fundou o Jornal de Debates com Gasparian e reorganizou o Última hora. Ele que tinha tantos amigos jornalistas, escritores. O.K., jornalismo entăo (PAIVA, 2015, p.190).

Estamos na terceira e última parte de Ainda estou aqui, momento em que Marcelo Rubens Paiva admite já ter narrado sobre o empenho de Eunice para se reerguer, construir uma carreira como advogada, sua atuaçăo política. Admite já ter dito tudo sobre as décadas em que sua măe defendeu as causas indígenas, sua atuaçăo política, reafirma que ela é a grande heroína de sua família, e, ao leitor, resta os questionamentos: a repetiçâo é inerente à escrita de memórias? Memórias sâo cíclicas e por isso o 
narrador se movimenta indo e vindo entre a narraçăo e o comentário?

A repetiçáo faz parte da homenagem - é uma ressalva para a importância da biografia de sua măe, ao passo que, devido ao Alzheimer, está desaparecendo. Fato descrito como um drama cruel, uma grande injustiça. Você se lembra de mim? é a pergunta que todos lhe fazem, e é mais uma oportunidade para se comentar sobre a memória:

\begin{abstract}
A memória năo se acumula sobre outra. A recente năo é resgatada antes da milésima. Que náo fica esquecida sob o peso das novidades, do presente. O passado interage com o segundo vivido, que já ficou para trás, virou memória recente. Memórias se embaralham. Entăo me explica rápido: por que velhos com demência se esquecem das coisas vividas horas antes e se lembram das vividas na infância, décadas antes? Minha măe, aos oitenta e cinco anos de idade, com Alzheimer, năo se lembra do que comeu no café da manhă. Mas vê meu filho, de um ano e pouco, e o reconhece, como pouquíssimas pessoas (PAIVA, 2015, p. 191).
\end{abstract}

Nessa passagem, o narrador se questiona sobre a incoerência de sua mâe com demência reconhecer seu filho. Nesse questionar, expóe suas dúvidas, ao mesmo tempo em que responde com a hipótese de que, ao se embaralhar, as memórias podem causar sentido. Será no embaralhar que ela reconhece seu filho apesar de náo se lembrar do que comeu no café da manhă? O que suscita mais uma alternância narrativa, pois o autor implícito, novamente, se passa por narrador e ressalta a memória construída, "que năo se acumula sobre a outra", comprovando as diversas possibilidades de se narrar em primeira pessoa.

Quando chegamos ao capítulo Já falei do suflê, temos a nítida impressăo de que é o momento em que a heroína começa, depois de muitas agruras, a colecionar vitórias. É o ponto alto da homenagem, o início de uma virada em um jogo cujas regras sempre foram desonestas e, no entanto, aos poucos iam se tornando mais equilibradas.

O autor descreve seus anos no curso de engenharia agrícola na Unicamp no final dos anos setenta, e faz a oposiçăo: enquanto vivia com poucos recursos, realizava trabalhos temporários, morava em pensôes e depois repúblicas estudantis, sua mâe năo deixava o seu padrăo de vida cair.

Nunca entendi a necessidade que ela tinha de oferecer algo que estava fora dos padrōes, de demonstrar uma falsa estabilidade financeira. Insegura que era, talvez fosse a maneira que encontrou de encarar o luto: minha vida mudou, mas năo a eliminaram. A ressaca dos seus amigos era menos importante do que a sensaçăo de que a Eunice está bem, está viva, está magra, bonita, bem vestida, está se virando, sem fazer drama, sem reclamar, sem pedir nada. Sua vingança era a cabeça erguida, a pose de quem saber enfrentar os inimigos (PAIVA, 2015, p. 200).

Além de ilustrar a descriçăo do referido capítulo, a passagem também indica que a chamada construçâo ficcional é desenvolvida através de uma escrita memorialista calcada em aspectos implícitos cuidadosamente escolhidos pelo narrador testemunha, e comentador, duplicado em um só para impactar năo só a narrativa, como também o leitor que é manipulado; emociona-se com a dignidade da personagem que náo faz drama, que năo reclama, năo pede nada. 
Ao longo dessa divisáo, Eunice é descrita como muitas, măe que manteve tradiçóes familiares (como a de cozinhar, por isso a alusâo ao suflê), mas ao mesmo tempo nâo cobrava muito dos filhos, transitava por diferentes causas, voltou a sorrir, a dançar, a namorar. Ajudou a reconstruir a memória do marido desaparecido e apesar de todas as novidades profissionais, năo deixava de ser măe.

Ao se empenhar na manipulaçăo, o trabalho do narrador deixa revelar outro exemplo da atuaçâo estratégica do autor implícito que se afirma como responsável teleológico pela narraçáo. $O$ choro final pode ser resumido como o capítulo no qual sâo narradas as últimas descobertas feitas por Eunice sobre o ocorrido com Rubens Paiva antes de ser diagnosticada com Alzheimer. Em 1986, as respostas começaram a serem dadas; o depoimento do médico Amílcar Lobo que relatava ter atendido o ex-deputado e atestava que o preso apresentando indícios de violenta tortura năo tinha resistido. Depois de quinze anos, a família de Rubens Paiva ouviu o silêncio ser rompido:

Conhecendo a minha măe, tinha uma esperteza aí. O que nos interessava? Que Lobo abrisse o bico, falasse mais, desse nomes, apontasse culpados, e, enfim, revelasse o lugar onde estaria a ossada. Perdoá-lo seria ganhar um aliado, trazer para o nosso lado. Lobo era o primeiro de dentro do regime a falar. Quem sabe outros se sentiriam encorajados. Deu certo. Ele falou tudo o que sabia, sentiu-se encorajado, até escreveu um livro com detalhes. Mas ele nâo sabia tanto assim. Era uma personagem secundária na máquina de triturar ossos. Morreu poucos anos depois (PAIVA, 2015, p. 219).

No trecho destacado, o narrador supóe uma intençâo da mâe e reforça com um questionamento que transforma essa personagem em representante da família; há um deslocamento da terceira pessoa ela (a măe) para a primeira (nos interessava?), a narrativa se movimenta ("Que Lobo abrisse o bico") e, quando a terceira pessoa é estabelecida, comenta com o verbo no passado perfeito ("Deu certo"), concluindo o comentário sarcasticamente.

A narrativa aqui deixa de ter o seu habitual predomínio de sentido nas memórias reconstituídas, para promover outro; o da gradaçăo. $O$ autor, transvestido de narrador, lança máo desse recurso buscando evitar a monotonia, uma vez que vários capítulos săo dedicados à biografia da măe. Devido a esse recurso, os acontecimentos e feitos que reconstruídos caracterizam a história dessa personagem sâo narrados gradativamente para que, ao final, o leitor năo desista, ao contrário, esteja ainda mais perto desse narrador.

Por isso, na sequência, outra vitória de Eunice é rememorada com detalhes cuidadosamente escolhidos e, assim, o leitor redimensiona as agruras pelas quais essa mulher passou e pode se comover quando é colocado diante do episódio em que ela obtém , depois de vinte e cinco anos de tentativas, o atestado de óbito do marido, a decretaçâo oficial de sua viuvez precoce:

Meu pai pedia remédios e água. [...] Você sabe, mamăe, por que foram levadas ao DOI? Ele năo falava nada. Repetia o nome. Foi torturado no dia 20. Nada. Retomaram no dia 21. Com a filha e a mulher encapuzadas, sentadas num banquinho. Será que viu vocês? Como ele reagiria? O que ele faria, para impedir que encostassem em vocês? 
Qual era a saída? A única saída? [...] Naquela tarde que pegamos o atestado de óbito, em 1996, vi minha máe entâo chorar como nunca. (PAIVA, 2015, p. 224)

Além de ilustrar o episódio de recebimento do atestado de óbito de Rubens Paiva, no acima, o narrador se desloca no tempo, entre 1971 e 1996, como se estivesse presente nos dois eventos. Há momentos em que narra como se estivesse preso junto ao pai, presenciando seu suplício e a sua resistência: "ele năo falava nada", mas nesse episódio năo foi testemunha, entăo supóe: "Será que viu vocês?" E prossegue com perguntas que năo tem respostas até vinte e cinco anos depois ser atestada a morte desse (seu) herói. Nessa passagem, o narrador náo se movimenta apenas pelas datas dos acontecimentos, ele age a partir da flexibilidade existente entre o narrar e comentar e conclui "vi minha măe entâo chorar como nunca", volta ao presente, ele perfaz um ciclo temporal carregado de perguntas, dúvidas, condiçóes que na presente narrativa săo constantes.

Em 1999, outro recuo no passado: Eunice decide se aposentar e voltar a morar no Rio de Janeiro. Voltava viúva, voltava após os filhos terem crescido, após ter cumprido a missăo de ser máe e pai, após todos estarem encaminhados na vida. Iria desfrutar do patrimônio que conseguira construir quando se reconstruía, por um tempo deu certo, só o que ninguém esperava era a chegada inesperada daquilo que ficou sendo apelidado de $O$ alemâo impronunciável.

O penúltimo capítulo de Ainda estou aqui detalha o drama de uma família que passa a conviver com o Alzheimer:

No início, nos afligia, nos entristecia náo satisfazê-la. Tudo era uma "por-ca-ria". 0 que fazer com ela? [...] Sair com ela em público podia trazer problemas. Ela podia implicar com alguém. - Por que está me olhando? Nha-nha-nha. Falem baixo, por favor! Nâo gosto dela. Năo gosto de você. Ou o grito que se tornava constante: - Quero ir embora!Náo, năo é a sua máe (PAIVA, 2015, p. 237).

Nessa passagem, a nova condiçăo de Eunice é introduzida através da expressâo nominal "No início", que nos remete à locuçâo "era uma vez", comum nas narrativas orais como mitos, lendas e fábulas. Nâo é uma escolha desproposital; serve como uma circunstância temporal para sinalizar a mais nova tragédia da família: o lento apagar de sua grande referência.

Novamente, o narrador pergunta-se sobre o que fazer com a mâe, afinal, ela năo é mais a figura forte e sólida, mas sofria rachaduras, deixava de ser inquebrável, deixava de ser um exemplo de comportamento social e, nesse momento, o narrador se passa por Eunice, assumindo, por vezes, a sua voz.

O livro termina com a pergunta que é título de capítulo e também chave para encerrar o ciclo dessas memórias: $O$ que estou fazendo aqui? Mais uma vez, o autor considera que memórias se misturam, nunca estăo enfileiradas, por vezes se sobrepóem dentro das inúmeras possibilidades de retençấo da memória, para tentar compreender como sua mâe, no estágio terceiro do Alzheimer, nâo se lembra mais de como é andar, se já dormiu, se já se esquece de como se faz para engolir - o reconhece, reconhece seu filho e, apesar de todo alheamento, recorda do marido quando este é noticiado na televisâo anos após sua morte. 
O autor-narrador nesse trecho final afirma que năo existe uma explicaçăo plausível para tais lapsos de lucidez, que Eunice vai morrer quando năo conseguir mais deglutir, que se apagará pondo fim a uma história de incríveis recomeços, mas morrerá sempre surpreendendo:

Seu orgulho era maior que seu esquecimento. Jamais sentiria pena de si mesma. Nem queria que sentíssemos pena dela. Jamais pediu ajuda. Recentemente, uma nova fala cheia de significados entrou no seu repertório, especialmente quando um turbilhăo de emoçóes a ataca, como rever uma filha que mora na Europa ou segurar no colo o meu filho, o que mostra uma felicidade e um alerta, caso alguém năo tenha reparado: Eu ainda estou aqui. Ainda estou aqui (PAIVA, 2015, p. 262).

No exemplo acima, novamente o recurso da gradaçăo para enaltecer a história de uma personagem orgulhosa que está se esvaindo pelas ondas do esquecimento feito uma vela que lentamente se apaga, nesse caso, as diferenças ou opostos entre estar e nâo estar presente reforça o perfeito funcionamento da linguagem empregada. Nessa reta final, outra vez podemos comprovar o duplo movimento do narrador porque nessa passagem, o autor continua reconstruindo suas memórias e a de seus pais, intercalando recordaçóes relevantes e rupturas para causar continuidade, para realizar um trabalho de escrita metanarrativo.

Portanto, sem abandonar o aspecto narrativo retrospectivo, as memórias sāo elencadas entre o que se pode considerar fatos narrados e comentários a partir de um narrador que faz revelar o trabalho de um autor implícito e estabelece graus de verdades para o presente trabalho de reconstituiçăo histórico memorial.

\section{AINDA ESTOU AQUI, OU SOBRE COMO NÃO IR EMBORA}

Ainda estou aqui mostra-se estruturado a partir de três eixos: o primeiro consiste na celebraçáo da paternidade e o desejo de registrar a memória nova do filho, que está crescendo e desenvolvendo uma memória sobre a qual já é possível refletir as vivências entre pai e filho. Essa criança, quando adulta, também terá uma figura paterna para se lembrar, orgulhar, ser influenciada. A memória como herança, como valores que săo passados através dos laços familiares, tem seu caráter fluído, contínuo reforçado. Como pode ser visto no trecho:

\footnotetext{
Em fevereiro de 2014 nasceu meu filho. Talvez, de alguma forma, ele vá se lembrar de quando nasceu: verá fotos e filmes de como era gostoso fazer da minha barriga um tambor, da minha perna, uma escada, da minha cadeira de rodas, um andador, e de como ele gargalhava quando eu assoprava o seu cabelo, colocava um chapéu em mim e depois nele...(PAIVA, 2015, p.31)
}

Trata-se de uma passagem em que o narrador supóe que o filho terá memória de quando nasceu e dos primeiros feitos realizados no seu primeiro ano de vida, a presença do advérbio "talvez" seguido da expressăo "de alguma forma" reforça o ato da construçâo ficcional dessa memória permeado pela dúvida, pois, nâo é certeza de que já temos memória nessa idade. Porém, o nascimento do filho faz desse autor pai, e essa condiçấo 
nova, além de ser um dos motivos para a feitura desse livro, também reverbera em outro: a reconstituiçấo da memória de Rubens Paiva pelo seu filho Marcelo, que tinha apenas onze anos quando os momentos de convívio com o pai sofre efetivamente uma ruptura - săo poucas as lembranças ao lado desse pai: faz-se necessário reconstituí-lo ficcionalmente. $\mathrm{O}$ autor/narrador gora também é pai e, por isso, se configura, nesse momento, um outro movimento: cíclico. Capaz de reconstruir e valorizar as memórias que compóem esse laço tâo especial que é a relaçăo entre pai e filho.

Considerando os motivos para a escrita dessas memórias, chegamos ao segundo pilar dessa narrativa que é a outra reconstituiçăo de Rubens Paiva; o resgate de sua história (e memória) pela Comissăo Nacional da Verdade (CNV). O trabalho de investigaçăo realizado em parceria com o Ministério Público Federal do Rio de Janeiro elucidou o caso explicando os motivos da prisăo, morte por tortura e ocultaçấo dos restos mortais do ex-deputado pela polícia política do DOI Codi em 1971. E, dessa maneira, o narrador descarrega:

A tática do desaparecimento é a mais cruel de todas, pois a vítima permanece viva no dia a dia. [...] Só recentemente o quebra-cabeça foi completado pelo Ministério Público Federal do Rio de Janeiro. Nos cinquenta anos do golpe militar, tivemos a conclusăo[...] Foi quase completado. Está tudo na internet. Até no YouTube. É público. Falta o principal, o corpo. (PAIVA, 2015, p. 165)

O terceiro eixo que edifica Ainda estou aqui constitui-se na homenagem a Eunice Paiva reverenciada pela necessidade do autor em escrever a sua biografia. Essa personagem divide, com o autor, o papel de protagonista e é descrita como a grande heroína da família, por várias vezes considerada ícone: da luta contra a ditadura, na campanha pela anistia, no processo de abertura e democratizaçăo, pela atuaçăo no movimento pelas diretas já. Eunice foi ícone e heroína por nunca ter se acovardado e ter ensinado aos filhos que a perda sofrida por eles fazia parte de um contexto maior, náo cabia pieguismos, revanchismos, cabia ajudar a concretizar um projeto que abarcasse as demais famílias também vítimas da truculência política.

Trata-se da terceira memória a ser resgatada, pois tal biografia náo pode ser apagada, esquecida junto ao Alzheimer, diante de mais esse drama, o autor comove, pois, realiza um verdadeiro acerto de contas com essa măe e, ao mesmo tempo, delineia uma homenagem perpetuando sua história. Ressaltando nâo se tratar de uma história qualquer e aproveitando para chamar a atençăo daqueles que por ignorância ou desconhecimento histórico apregoam a volta dos militares ao poder, no apagamento da memória de Eunice reside uma alusão: a de saber que a memória coletiva também se dissipa. E, por isso, as contundentes atuaçóes e vitórias tardias dessa personagem podem auxiliar as novas geraçóes a conhecerem e entenderem um período especial da História do Brasil que está começando a ser ensinado nas escolas e debatido nos meios midiáticos. Nesse sentido, podemos afirmar que ao encadear as razóes para a escrita de Ainda estou aqui, o autor conseguiu reproduzir a tríade da tentativa (bem-sucedida) de realizar um projeto narrativo.

Em Ainda estou aqui os modos de reconstituiçấo da memória săo também os modos de escrever "uma história da história", conforme nos ensina Gagnebin (2006, p. 39). Como já dito, da escrita das memórias se depreende um interesse do autor em 
torná-las verdade, reforçando a importância de seu projeto de resgate das biografias de seus pais em um momento de reflexăo política (manifestaçōes populares contra e a favor do governo brasileiro em 2015) suscitando um debate aparentemente esquecido.

Considerando que Marcelo Rubens Paiva revive suas memórias “articulando o passado" (2006, p. 40), preenchendo os vazios (năo testemunhados) com criaçôes literárias resultantes das releituras de versôes que lhe foram contadas, impregnadas de subjetividade de um tempo posterior carregado de justificativas para os acontecimentos; a narrativa é fabricada por um autor/narrador consciente da "estreita fronteira entre a memória histórica" (GAGNEBIM, 2006, p. 41) e as memórias (histórias) reconstituídas e, sendo dessa natureza, a narrativa impacta; convence, afeta o leitor pela imposiçâo do peso do real.

A organizaçấo interna do objeto de análise reflete um processo de recuperaçâo da memória desencadeado pela dor, os traumas săo elencados com certa cronologia, porém náo linear: um mais antigo se cruza com outro e, por vezes, parecem indissociáveis. Possivelmente justificada na matéria ou substância do que ele está narrando: a perda precoce do pai, o acidente de sequelas irreversíveis, a inaceitável demência da máe. Trata-se de experiências tăo singulares que năo podem ser contadas nos moldes de uma escrita comum.

A chamada narraçăo tradicional năo permitiria uma construçăo de memórias que pudesse agir contra o esquecimento; por isso, apesar de todo pesar, o ato de narrar perpetua, transforma, provoca renascimentos. As memórias de Rubens e Eunice Paiva estăo restauradas e prontas para oferecerem sentido às geraçôes futuras. Na versâo oficial sobre o pai náo cabem as consequências subjetivas provocadas por esse desaparecimento, năo é possível esquecer, năo é possível reconstruir os fatos por muito tempo apagados pela imposiçăo de um regime opressor sem a devida contaminaçăo do estrago emocional instaurado na ruptura.

Assim, retornando aos aspectos narrativos em Ainda estou aqui, é possível considerar a alternância entre narraçáo e comentário (revelador de um caráter metanarrativo, portanto) como uma espécie de sintoma inevitável de um narrador que trabalha a sua narraçăo como se fosse um "narrador sucateiro" (GAGNEBIM, 2006, p. 54), quando decide reunir as provas que refutam a versăo inicial sobre o desaparecimento de seu pai, reaproveitando resíduos descartados, ignorados em nome de um discurso fantasioso, mas por muito tempo tomado como oficial, real.

Nesse sentido, Marcelo Rubens Paiva vê-se diante da tarefa essencial, porém inglória, de narrar o inenarrável, posiçấo próxima à que se refere Gagnebin ao caracterizar o historiador atual, o qual

(...) precisa transmitir o inenarrável, manter viva a memória dos sem-nome, ser fiel aos mortos que náo puderam ser enterrados. Sua "narrativa afirma que o inesquecível existe" mesmo se nós năo podemos descrevê-lo. Tarefa altamente política: lutar contra o esquecimento e a denegaçăo é também lutar contra a repetiçăo do horror (que, infelizmente, se reproduz constantemente). Tarefa igualmente ética e, num sentido amplo, especificamente psíquica: as palavras do historiador ajudam a enterrar os mortos do passado e a cavar um túmulo para aqueles que dele foram privados. Trabalho de luto que nos deve ajudar, nós, os vivos, a nos lembrarmos dos mortos para melhor viver hoje. Assim, a preocupaçấo com a verdade do passado se completa na exigência de um presente que, também, possa ser verdadeiro. (GAGNEBIM, 2006, p. 47) 
Ao narrar e comentar o que narra, Marcelo Rubens Paiva chama a atençăo para o caráter relativo das verdades construídas, ao mesmo tempo que legitima o presente instaurado por sua narrativa como uma possibilidade, como verdadeiro, portanto, justamente por se assumir metanarrativamente como construçăo.

Marcelo Rubens Paiva constrói o testemunho do sofrimento acarretado por traumas de várias espécies; entretanto, tem a peculiaridade de năo ter sido, em vários aspectos, uma testemunha ocular desse passado, ou seja, foi testemunha, mas năo pôde testemunhar, uma vez que sempre lhe foi tirado o direito de saber a verdade. O que só adiciona sentido a essa tentativa de interpretaçăo para a retórica ficcional: ele é um tipo particular de testemunha, essa é uma outra justificativa para o modo de comportamento peculiar de um autor que depreendemos implícito em sua narrativa, para a estratégia da alternância, do jogo duplo em todo o percurso narrativo de Ainda estou aqui.

Gagnebin, ao trabalhar a relaçăo entre memória, história e testemunho, refere-se à chamada morte da narrativa indicada por Walter Benjamim, a qual, por seu turno seria um sintoma do que identifica como sendo a perda do sentido forte da experiência, aquela que pode ser transmitida de geraçăo para geraçăo, de pai para filho, por meio da tradiçấo, portanto. Uma das razôes de a experiência năo poder ser transmitida seria justamente pelo fato de ela ser aniquiladora, seja porque năo há sobreviventes para relatar a experiência, seja porque esta năo vale a pena ser lembrada (deve ser esquecida, pois náo há nada para aprender, nâo há uma tradiçâo a ser transmitida), ou mesmo porque o peso do relato da experiência é tăo forte que se torna insuportável. Diante de uma narrativa insuportável, resta ao ouvinte retirar-se, portanto, ir embora, negar-se a testemunhar a narrativa de sofrimento. Diante disso, Gagnebin entende ser necessária a ampliaçăo do conceito de testemunha; no sentido de que testemunha năo seria apenas aquele que viu com seus próprios olhos, mas

também seria aquele que năo vai embora, que consegue ouvir a narraçáo insuportável do outro e que aceita que suas palavras levem adiante, como num revezamento, a história do outro: năo por culpabilidade ou por compaixăo, mas porque somente a transmissáo simbólica, assumida apesar e por causa do sofrimento indizível, somente essa retomada reflexiva do passado pode nos ajudar a nâo repeti-lo infinitamente, mas a ousar esboçar uma outra história, a inventar o presente (GAGNEBIN, 2006, p. 54).

Sob esse prisma, é possível considerar que ao construir o seu Ainda estou aqui, Marcelo Rubens Paiva recusa-se a ir embora; seja para se constituir como uma testemunha (e construtor) da história insuportável sobre o desaparecimento de seu pai; seja para ser a testemunha da memória evanescente de sua măe, seja para constituir-se como testemunha de si, vendo-se como outro filtrado pela lente do tempo. Esse testemunho, portanto, só pode se dar, como diz Gagnebin, por uma "retomada reflexiva do passado", em que o narrado nunca aparece sem se denunciar como construçấo, sem desconfiar de si mesmo por meio de uma referencialidade metanarrativa, de onde, justamente, extrai toda a sua força e potência para se impor como verdade capaz de inventar o presente. Inventado o seu presente, Marcelo Rubens Paiva năo é apenas uma testemunha que resiste, mas, sobretudo, recusa-se a aceitar que Rubens e Eunice Paiva possam simplesmente ir embora. 


\section{REFERÊNCIAS}

BOOTH, Wayne C. Narradores Fidedignos como porta-vozes dramatizados do autor implícito. In. A retórica da Ficçâo. 1. ed. Lisboa: Arcádia,1980, p. 227 - 231.

DAL FARRA, Maria Lúcia. O narrador ensimesmado. 1.ed. Sāo Paulo: Ática, 1978.

GAGNEBIN, Jeane Marie. Lembrar, escrever, esquecer. Săo Paulo: Ed. 34, 2006.

GENETTE, Gérard. Fronteiras da Narrativa. In: BRATHES, R. et alli. Análise Estrutural da Narrativa. Ed. Vozes: Rio de Janeiro, 1976, págs. 255- 274.

LEJEUNE, Philippe. O pacto autobiográfico: de Rousseau à Internet. 2. Traduçăo: Jovita Maria Gerheim Noronha e Maria Inês Coimbra, Belo Horizonte: UFMG, 2014.

NUNES, Benedito. O tempo da narrativa. Săo Paulo: Ática, 2003.

PAIVA, Marcelo Rubens. Ainda estou aqui. 1. Ed. Rio de Janeiro: Alfaguara/Objetiva, 2015. 